ISSN 1112-9867

http://www.jfas.info

\title{
GEOCHEMICAL CHARACTERIZATION THE WATERS OF FOGGARAS THE CONTINENTAL INTERCALARY AQUIFER OF TIMINOUNE REGION (SOUTH WEST ALGERIA)
}

B. Benaricha*, A. Khaldi, A. Elouissi, S. Mouassa, M. Zaagane

Laboratoire de Recherche sur les Systèmes Biologiques et la Géomatique, Université de Mascara, BP 305, Mascara, 29000, Algérie

Received: 08 Jully 2016 / Accepted: 21 November 2016 / Published online: 01 January 2017

\begin{abstract}
The study of the Continental Intercalary (C.I) groundwater of the region of Timimoune (southwestern Algeria), based on physico-chemical data (major elements), allowed to understand the geochemistry of foggaras water. The aquifer is contained in the formations of the Lower Cretaceous (Albian and Barremian). The waters are strongly mineralized with an average value $2 \mathrm{~g} / 1$.The waters have a clear predominance of facies chlorinated-sodium. The risk is high to excessive soil salinization, and the risk of medium alkalinity to very high. Statistical analysis led us to reach two conclusions, the first is that, variable electrical conductivity (EC), dry residue (RS), $\mathrm{Na}^{+}, \mathrm{Ca}^{2+}, \mathrm{Cl}^{-}, \mathrm{SO}_{4}^{--}$, mineralization, are best correlated and responsible the signing of the mineral load of water, the second is that the nitrate ion $\left(\mathrm{NO}_{3}{ }^{-}\right)$opposite to the above-mentioned variables mark its anthropogenic origin.
\end{abstract}

Keywords: Continental Intercalary, mineralization, salinity, PCA, Nitrate

Author Correspondence, e-mail: benarichab@yahoo.fr

doi: http://dx.doi.org/10.4314/jfas.v9i1.5 


\section{INTRODUCTION}

Water surrounds us everywhere but the one man considers as direct use is limited. Most $(97.5 \%)$ of this water is salty kind, the rest $(2.5 \%)$ is a freshwater of which only $1 / 3$ of $1 \%$ of the total volume is the flow of rivers, and the stock of groundwater.

In the desert areas of the Maghreb (Algeria, Tunisia, Libya), there is a reserve of not very renewable fossil water. It is represented by two large tanks of two sedimentary basins called transboundary aquifers: the Terminal Complex (T.C) and the Continental Intercalary (C.I). In the Saharan regions, known for low rainfall, these aquifers are the only water resource for supplying the population and irrigation of gardens Saharan oasis, immutable constellation of green patches on this immense desert of sand and rocks. These totally manmade spaces are representing intensive production systems of great complexity now in almost fragile balance.

In Algeria, oasis occupies an area of 93,000 ha with over 10 million date palms, $11 \%$ of the world total. The culture of the date palm and to lesser extent vegetable constitutes the only resources of the population in desert areas.

Timimoune (part of Adrar, province of Algeria), hyper arid, is a part of the oasis which is less supplied by the water of Foggaras system from the underground water of Albian Continental midsole. The fougaras irrigation technique is to install a slightly sloping gallery that drains water from the web to the surface. The collection of water is by gravity and in a continuous manner without any human or animal effort. This system has functioned for centuries, but it continues to operate its decline seems quite inevitable. Population growth, salinity, pollution and over-exploitation by abusive exploitation drilling are factors in its decline.

Many authors have focused on the descriptive and functional side that is to say, implementation, management, water allocation of water of foggaras, others has given the alarm about declining rates view even their tarissements and collapses. The study proposed in this work aims to make a geochemical analysis of Fouggara water in the area of Timimoune used for irrigation of the palm. These waters are also used by locals for consumption because the area has not yet a full drinking water network of A.D.E. (Algerian Des Eaux), and not even with a sewerage system, the only way to sewage remains septic tanks. 


\subsection{Study area}

Timimoune is a town in the province of Adrar, and it is the capital of Gourara region in south-west of Algeria (Fig.1). It is situated in an altitude of 293 meter, latitude $29^{\circ} 15^{\prime} 49^{\prime \prime}$ North to Tademaït hill in the west, and from $0^{\circ} 13^{\prime} 51^{\prime \prime}$ of east longitude. It dominates Sebkha (depression and place of salty water evaporation) which is the former site of what was sometimes a river, and the other times lacustrine scope. This pool has received many sediment phases; it is rich in fossils and hydrocarbons. It is in the center of triangle which is formed by the southern fringe of the occidental Erg, the North-west border of Tademait hill, and to the west of Saoura-Messaoud west side. This vast hill of over than $100 \mathrm{Km}$ of width and surface of nearly $10.500 \mathrm{~km}^{2}$, in which a numerous depressions of type sebkha enroll (Timimoune Sebkha is measured by $80 \mathrm{~km}^{2}$ ). All, more or less scattered massive dunes, sometimes even entirely covered by ergs, forming the Gourara which is extended on surface of around $86.000 \mathrm{~km}^{2}$. This region contains almost a hundred Ksours (traditional villages) and oasis (Tinerkouk, Swani, Tagouzi, Aougrout, Deldoul), they are hung in cliffs festoons, at the limestone uplands of Tademaït, in hidden bowl between dunes of Occidental Great Erg.

In the North-west all the way to Bechar, there is a semi-desert climate, desert in the south-west to Timiaouine. The temperature differences are important in the summer with a maximum of $45^{\circ} \mathrm{C}$ and a minimum around $5^{\circ} \mathrm{C}$. The wind is frequent with a speed of $25 \mathrm{~km} / \mathrm{h}$, the sirocco reaches $100 \mathrm{~km} / \mathrm{h}$. The pluviometry is less than $18 \mathrm{~mm} / \mathrm{year}$; the humidity rate is around $40 \%$.

The flora of oasis consists of date palms and vegetable corps. It is irrigated by Continental Intercalary (Albien) with a help of an ancestral hydraulic system called Foggara. The oasis is limited in the south-west by the town of Timimoune and by occidental Erg and Sebkha in North-west. 


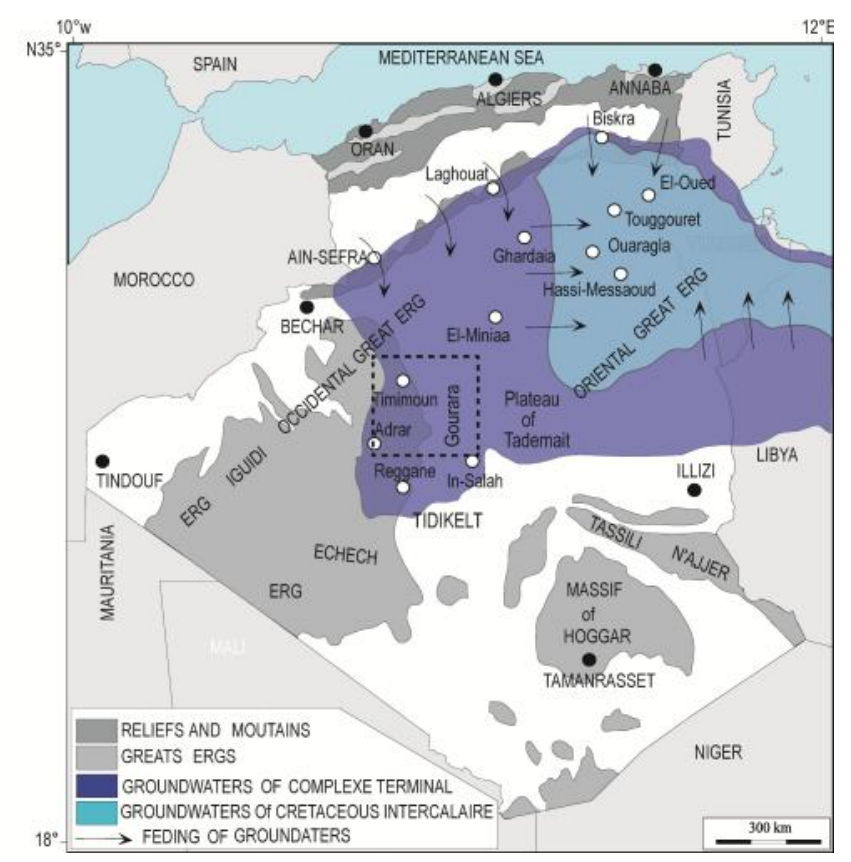

Fig.1. Map showing the geographical location of the study area (dotted Square) and geographic extensions of the groundwater of the Continental Intercalary (C.I.) and Terminal Complex (T.C.)

\subsection{Geology and Hydrogeology}

Timimoune basin is situated in NW of the Saharian platform. It forms a depression in elongated gutter NW-SE over a length of $500 \mathrm{~km}$ and a width of $300 \mathrm{~km}$, which is a surface around $150.000 \mathrm{~km}^{2}$. On the lithostratigraphic, the paleozoic forms the essential of the sedimentary cover. This coverage is jarring on a Precambrian pedestal or infracambrian whose depth varies between $1800 \mathrm{~m}$ in west and around 5500 to $6000 \mathrm{~m}$ in the center of the pool. All the paleozoic cycles are either sandstone, or clayey ad clayey-sandstone. Carbonate episodes are only known in Givetian and lower Franien.

The paleozoic is covered by the secondary transgressive depots layers that are generally flat. The Mesozoic average thickness is only of the order of $700 \mathrm{~m}$. The mesozoic cover is represented by the sedimentary series of lower cretaceous, it is constituted from top to bottom with the Albian, and the Barrémien which forms the Continental intercalary. These depots outcrop are: (i) straight in sub-surface, (ii) under a dune recovering of recent age or (iii) under a Pliocene-Quaternary covering [1] [2] [3] [4].

The continental episode is localized between two marine's sedimentary cycles: (i) in base, the 
paleozoic which completes the Hercynian orogeny, (ii) on the top, the superior cretaceous cycle. The Barremien of medium thickness of 276 meters, formed of thin sandstone to medium, carbonated, interposed i level of sandstone and dolomitic clays. The Aptien of medium thickness of $24 \mathrm{~m}$ formed of two dolomitic layers framing a level of clay. The Albien of thick detrital series of the order around $362 \mathrm{~m}$, tie in to an important aquifer horizon, it is represented in its totality by sandstone and silty clay (Fig.2).

The hydraulic pool includes a series of layers, aquifers which have been regrouped in three following types:

(i) the artesian aquifer called intercalary continental (or Albian's aquifer), is characterized by continental detrital formation between the paleozoic and the cenomanian marine. The waters of this aquifer flows into a reservoir that stretches over $600000 \mathrm{~km}^{2}$ from Libya to the west of Algeria [5];

(ii) the aquifer of the terminal complex (T.C) is characterized by the carbonated formations of superior cretaceous and tertiary detrital episodes and mainly the Miocene. The homogeneity of this aquifer waters (T.C) give a thought that these will be issued from the last fresh pluvial, that would be started around 14.500 years [6];

(iii) Both aquifers are surmounted by the water table which is presented in all oasis. In the north at the big occidental Erg, this groundwater is situated at Tertiaire continental formations from Saharan atlas to Gourara where it is mixed with C.I. Waters. The general circulation of waters in the occidental basin is the NNW to the SSE before being recovered in the direction of NE-SW by the depression drain of Gourara-Touat. On the other hand the limestone of Upper Cretaceous and the Eocene Terminal Complex (T.C.) are powered by the flow in the waters of Oueds from the Mzab dorsal [7]. A Sebkha Chaplet makes the underground waters outfall around which the water table has a shallow, is used by wells and fouggaras [8]. 


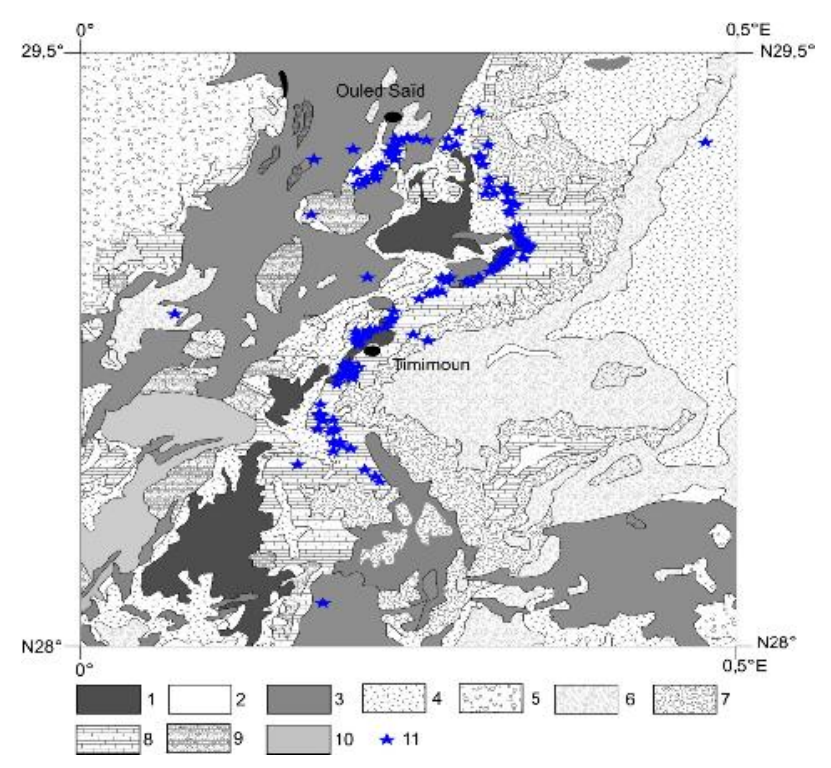

Fig. 2. Geological map of the study area location of sampling points 1 .Sebkhas and salt lakes recent 2.Recent Alluvium Rivers 3.Dunes 4. Former Quaternary 5.Neogene Continental 6.Continental Interlary (Albian) 7.Continental Intercalary (Barremian) 8. Continental intercalary (Cretaceous to Lower Barremian) 9.Lower Visean 10. Lower Tournaisien

\section{MATERIALS AND METHODS}

The Foggara waters that have been used for the analyzes came from Kasrias, triangular basin used to stock water before being distributed between the part owners of the palm gardens [9]. The samplings were carried out between January-April 2013. The collected water was packaged in opaque bottles and kept cold until arrival at the laboratory [10] [11].

Fifty four (54) samples of water were taken from the area of Timimoune (Fig.2). The physico-chemical analyzes are presented in two forms:

In situ for organoleptic parameters: color (visual observation), smell (feeling) and flavor (tasting) during the sampling. The physical parameters were determined at the time of taking the samples: a temperature using a field thermometer, $\mathrm{pH}$ by a $\mathrm{pH}$ meter WTW NOLAB. The electrical conductivity is measured by a ground conductivity type WTW LF 521. A field turbidity (NTU turbidity or nephelometric turbidity unit) to measure turbidity.

Chemical parameters were determined in the laboratory of the National Agency of Hydraulic Resources (N.A.H.R). The hardness or title hydrometric (TH) is determined by a complexometric determination by EDTA at $\mathrm{pH} 10$ using the Black of Eriochrome. The dry 
residue D.R. is obtained after passing through an oven at $110^{\circ} \mathrm{C}$ by double weighing. The bivalent cations $\mathrm{Ca}^{2+}$ and $\mathrm{Mg}^{2+}$ are determined by titration with EDTA (Ethylene diamino tetra acetic acid) the monovalent cations $\mathrm{Na}^{+}$and $\mathrm{K}^{+}$were determined by the flame spectrophotometer (PFP7). The $\mathrm{NO}_{2}^{-}$anions (nitrite) and nitrate $\left(\mathrm{NO}_{3}{ }^{-}\right)$, chloride $\left(\mathrm{Cl}^{-}\right)$, phosphate $\left(\mathrm{PO}_{4}{ }^{3-}\right)$ by colorimetry. Carbonates $\left(\mathrm{CO}_{3}{ }^{2-}\right)$ and bicarbonate $\left(\mathrm{HCO}_{3}{ }^{-}\right)$are determined by titration with sulfuric acid $\left(\mathrm{H}_{2} \mathrm{SO}_{4}\right)$. The oxidized organic matter is measured by potassium permanganate reduction.

To better visualize and characterize the physico-chemical data of the water, we used two complementary approaches, the charts ranking the water (chemical facies, salinity classes and alkalinities) the diagrams classifying waters. by the Avignon hydrochemistry software (AHS) Version 6 (2014) using diagrams Piper, and Richards, the other, a mathematical description of water by a principal component analysis (PCA) using Statistica version 6 software to study, the spatial distribution of water points in function of the physicochemical variables (variable constant temperature was discarded because it has no variance in the statistical treatment). Multivariate statistical approach allows us to make a comprehensive study of the data involved, to summarize, to represent them, to classify, visualize and define the relationships that may exist between the variables.

\section{RESULTS AND DISCUSSION}

\subsection{Physical parameters}

Organoleptic tests revealed no abnormality in the waters of foggaras. The turbidity values (NTU) are less than 5 ranking them as very clear waters. The hydrometric degree or hardness of water is the sum of the concentrations of calcium and magnesium [12]. According to the World Health Organization [13] hardness standards, water foggaras are 95\% hard to very hard $\left(\mathrm{TH}>32{ }^{\circ} \mathrm{F}\right.$ ), and only $5 \%$ hardness levels between $22-32{ }^{\circ} \mathrm{F}$ (enough fresh water) and this is related to the lithology of forming acquires and composition of magnesium and calcium. The hardness has consequences more or less harmful as excessive consumption of soap (when the water used is hard (high TH), fatty acids "neutralize" the calcium and magnesium from the water before it can act as agents detergents, hard water requires for the same detergency higher amount of soap a fresh water), poor cooking of pulses and the unacceptable taste. 
The temperature of the water is an important factor. It plays a role in the solubility of the gas in the separation of salts, the change in $\mathrm{pH}$, knowledge of the origin of the water and any mixtures, etc. In addition, this measure is important in limnology and in general, it is influenced by the source from which they come superficial or deep [14]. The water temperature is almost constant (all values are equal to 21 except for a one which is equal to 22). The $\mathrm{pH}$ depends on the origin of water, the geological nature of the substrate through [15] [16]. This setting affects many physical and chemical balances, and depends on many factors, including temperature and the source of water. It represents an important indication as regards the aggressiveness of the water (ability to dissolve lime). Hydrogen potential of the values are between 6 and 8.5 in natural waters [17], in terms of water foggaras of the zone, the $\mathrm{pH}$ is between 7 and 8 . The waters are highly mineralized with an average value $2 \mathrm{~g} / \mathrm{l}$.

\subsection{Evaluation of water quality}

The traditional irrigation system "Foggara" in the Algerian Sahara has allowed the transition from nomadic to sedentary. Uncontrolled irrigation little impact on plants and soils, as it can disrupt the development of plants and cause changes in soil structure [18]. To assess the quality of groundwater foggaras of Timimoune used in the oasis, we used the Piper diagram for determining the chemical facies, and Richards (1954) - chart "Riverside" [19] to understand the risk of salinization and soil sodisation. 


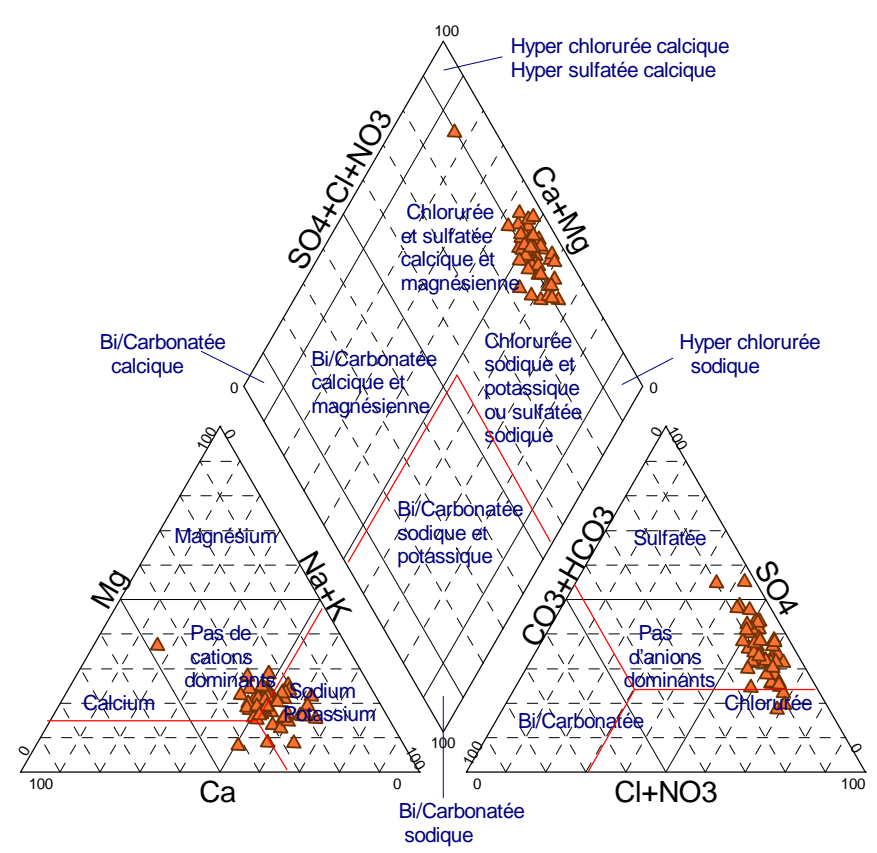

Fig.3 Facies of chemical groundwater Timimoune

\subsection{Determining the facies of chemical the waters}

The representation of the samples on the Piper diagram (Fig. 3) shows the existence in most samples $(90.74 \%)$ of a chemical-facies chlorinated sodium and potassium, and only $9.26 \%$ are calcium sulfatée- chemical facies depending on lithology that is crossing. These representative samples of the groundwater table Timimoune to show an alignment of the points that reflects changes between a sulfated lime facies and a chlorinated-sodic facies. These are the chlorides predominate in these waters, as well as sodium and potassium cations, resulting in the dissolution of evaporite salt formations.

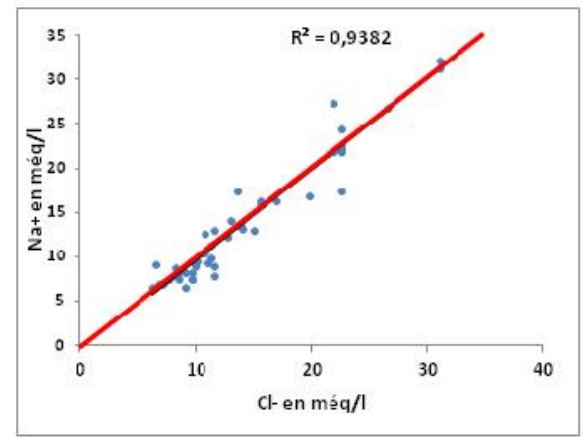

a. Right dissolution of halite

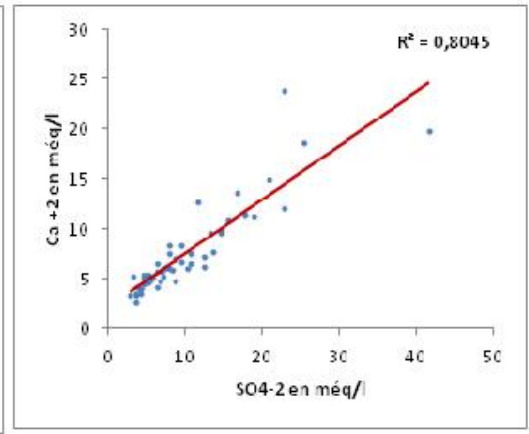

b. Right dissolution of gypsum 
Fig. 4. Relationship of $\mathrm{Na}^{+}$et $\mathrm{Cl}^{-}, \mathrm{Ca}^{2+}$ et $\mathrm{SO}_{4}{ }^{2-}$

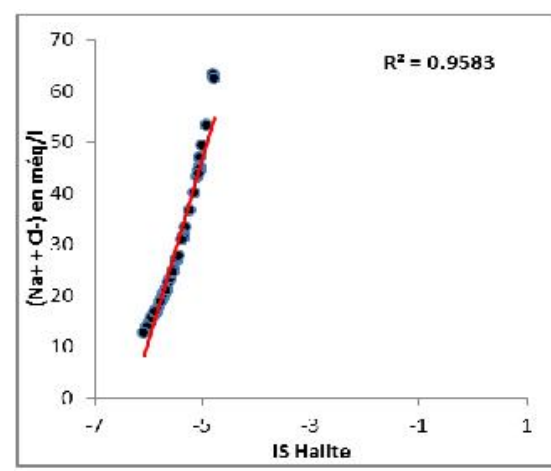

a.

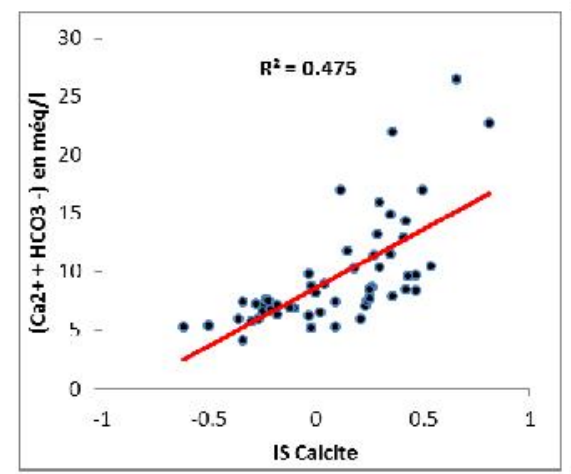

c.

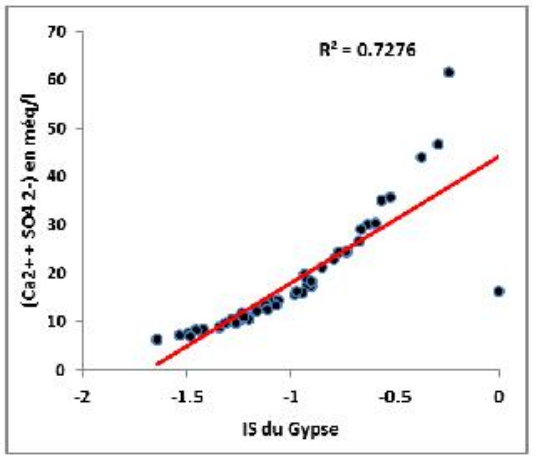

b.

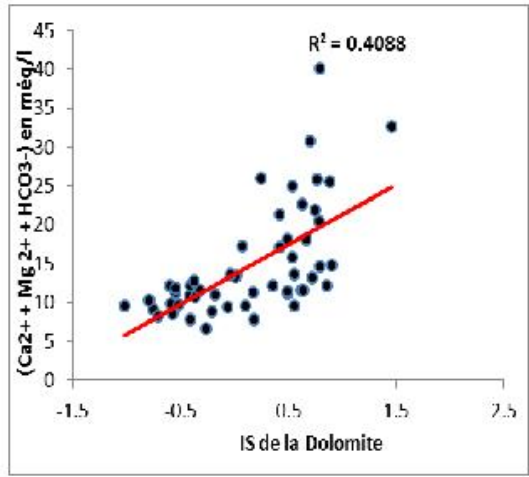

d.

Fig. 5. Correlation of saturation indices water of halite, gypsum, calcite and dolomite according $\mathrm{Na}+\mathrm{Cl}(\mathrm{a}), \mathrm{Ca}^{2+}+\mathrm{SO}_{4}^{--}(\mathrm{b}), \mathrm{Ca}+\mathrm{HCO}_{3}(\mathrm{c}), \mathrm{Ca}^{2+}+\mathrm{Mg}^{2+}+\mathrm{HCO}_{3}(\mathrm{~d})$ respectively, $\left(\mathrm{R}^{2}\right.$ coefficient of determination).

\subsection{Origin of mineralization}

\section{The reports $\mathrm{Na}^{+} / \mathrm{Cl}^{-}$and $\mathrm{Ca}^{2+} / \mathrm{SO}_{4}{ }^{2-}$}

The very good correlation between sodium $\mathrm{Na}^{+}$and $\mathrm{Cl}^{-}$Chloride $\left(\mathrm{R}^{2}=0.93\right)$ and the alignment points taken around and on the right side of the dissolution of the halite confirms the geological origin of these ions by the dissolution halite (Fig.4 a). The correlation between calcium $\mathrm{Ca}^{2+}$ and $\mathrm{SO}_{4}{ }^{2-}$ sulphate is good $\left(\mathrm{R}^{2}=0.80\right)$ confirms the dissolution of gypsum and the geological origin of the mineral (Fig.4.b).

\section{Saturation Index (SI)}

To determine the influence of the chemical elements, we used the thermodynamic tool by calculating the saturation index. According to the law of mass action, to an aqueous solution in equilibrium with a mineral, ion activity product (IAP) of the mineral is equal to the 
equilibrium constant (KSP) Thermodynamics. The degree of saturation of water can be represented by:

\section{SI $($ Saturation index $)=\log ($ IAP/KSP $)$}

This constant $\mathrm{K}$ characterizes the balance established in a reversible system which constantly evolving (for a given temperature). Noting that SI will be respectively zero, positive and negative to a solution equilibrium with the mineral solid phase considered, for under-saturation and for over-saturation towards the ionic elements concerned.

The saturation index calculated on 54 samples of water, the software integrated PHREEQ in Diagram software (LHA Simlers, 2013), is negative on all collected points, these waters are under-saturated in halite, encouraging the dissolution of this mineral (fig.5.a). For calcium and sulphate ions, the majority of samples are positioned around and on the right of the dissolution of gypsum, however certain samples are situated below this line indicating enrichment sulfate compared to the calcium (fig.4. b).

The index of saturation permitted us to note that these waters are under-saturated with gypsum, which favors the dissolution of this mineral, a point of water salt showed a saturation index equal to 0 indicating the saturation equilibrium with the gypsum (fig.5.b).

For calcite (fig.5.c), over $61 \%$ of water points collected are under-saturated with $37 \%$ of samples over-saturated and only $2 \%$ saturated with this mineral. However generally these waters favored the dissolution of calcite.

On dolomite (fig.5.d), groundwater of Timimoune for more than half of the samples $(57.40 \%)$ are over-saturated with dolomite, favoring the precipitation of this mineral, from where the poor correlation between this index and $\mathrm{Ca}^{2+}, \mathrm{Mg}^{2+}$ and $\mathrm{HCO}_{3}{ }^{-}$, however $42.60 \%$ of samples show a dolomite under-saturation translating the dissolution of this mineral.

\section{Index base exchange (I.b.e)}

According to [20], the cation exchange is a preferred setting mechanism of certain ions by clay minerals. In principle, and especially $\mathrm{K}^{+} \mathrm{Na}^{+}$of the solution are exchanged against $\mathrm{Ca}^{2+}$ and $\mathrm{Mg}^{2+}$ fixed in some mineral sites. Thus, if the contact time with the clay is quite long, the solution tends to become poorer in $\mathrm{Na}^{+}$and $\mathrm{K}^{+}$, and being enriched by $\mathrm{Ca}^{2+}$ and $\mathrm{Mg}^{2+}$. Increasing the concentration of $\mathrm{Na}^{+}$and $\mathrm{K}^{+}$cation exchange is evaluated by considering that 
precipitation water, or recharging, was ions balance between $\mathrm{Cl}^{-}$and $\left(\mathrm{Na}^{+}+\mathrm{K}^{+}\right)$. The use of index base exchange (I.b.e.) allows to highlight the water chemistry changes during its underground path. This index is the ratio of ion-exchanged and the same kind existing originally ions in water [21], we consider then the ion ratio as index cation exchange obtained by the following relationship:

\section{I.b.e $=[\mathbf{r C l}-\mathbf{r}(\mathrm{Na}+\mathrm{K})] / \mathbf{r C l}$}

- If I.b.e. is negative then $\mathrm{Ca}^{2+}$ and $\mathrm{Mg}^{2+}$ of water are exchanged against the $\mathrm{K}^{+}$ions and $\mathrm{Na}^{+}$ of the surrounding formations.

- If I.b.e. is positive then the $\mathrm{Na}^{+}$and $\mathrm{K}^{+}$ions of water are replaced by ions $\mathrm{Mg}^{2+}$ and $\mathrm{Ca}^{2+}$ of the surrounding formations.

- If I.b.e. $=0$ then there is a balance between the chemical compositions of the water and that of the surrounding ground.

Table 1. Statistical parameters of water for index Base Exchange

\begin{tabular}{|l|c|c|c|c|}
\hline $\begin{array}{l}\text { Stastical } \\
\text { parameters }\end{array}$ & Minimum & Maximum & Average & $\begin{array}{c}\text { Standard- } \\
\text { deviation }\end{array}$ \\
\hline $\begin{array}{l}\text { Index } \\
\text { exchange }\end{array}$ & 0.198 & -0.742 & -0.205 & 0.174 \\
\hline
\end{tabular}

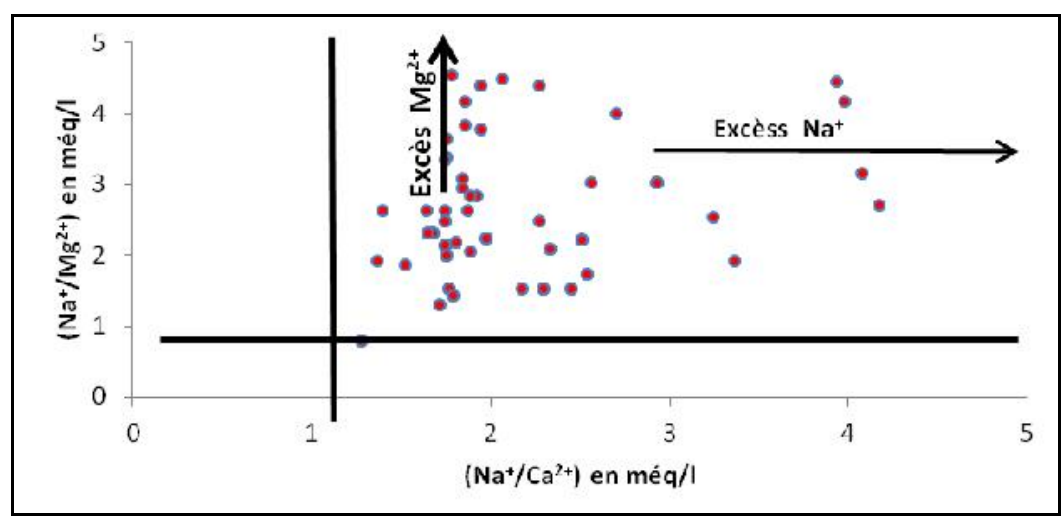

Fig.6. Relationship between the exchangeable ions in the water.

The characterization of ion exchange between the web and the aquifer defined I.b.e index is negative over more than $97 \%$ of the water samples, and varies between 0.19 and -0.74 (Table 1), the ions $\mathrm{Ca}^{2+}$ and $\mathrm{Mg}^{2+}$ of groundwater are exchanged against the $\mathrm{Na}^{+}$and $\mathrm{K}^{+}$ions of the surrounding clay formations. However groundwater of Timimoune reflect well this exchange, 
as they are richer in $\mathrm{Na}^{+}$compared to $\mathrm{Ca}^{2+}$ and $\mathrm{Mg}^{2+}$ (fig.6), this is due to lexiviage of halite in addition the contribution of the base exchange with the clay matrix. None of the index zero was recorded on all studied waters; positive values represent only $3 \%$.

\section{Geological origin of sodium salts}

The analyzed water is rich in sodium and chloride, which means a salt-bearing attachment of water. Geochemically, two sources seem workable to explain the saliferous source infill continental waters:

(i)an extrinsic origin: the supply groundwater map shows (fig.1) a north-south direction at the mountains of the Saharan Atlas, these mountains are represented by proportional anticlines track their hearts occupied by Triassic salt-bearing rocks, rainwater seep through the underlying formations to feed the sheet thus constituting an important element in the salinization of these waters;

(ii)an intrinsic origin: infill Continental is in the Albian formations are expected to have saliferous lifts affecting these formations. Chemical ions dissolved in contact with groundwater causing water salinization. The intrinsic origin seems more logical because in the overlying sedimentary procession gypsiferous the presence of clays and piles of gypsum (probable recovery of marine water) can probably be considered as an index of a local salinization. 


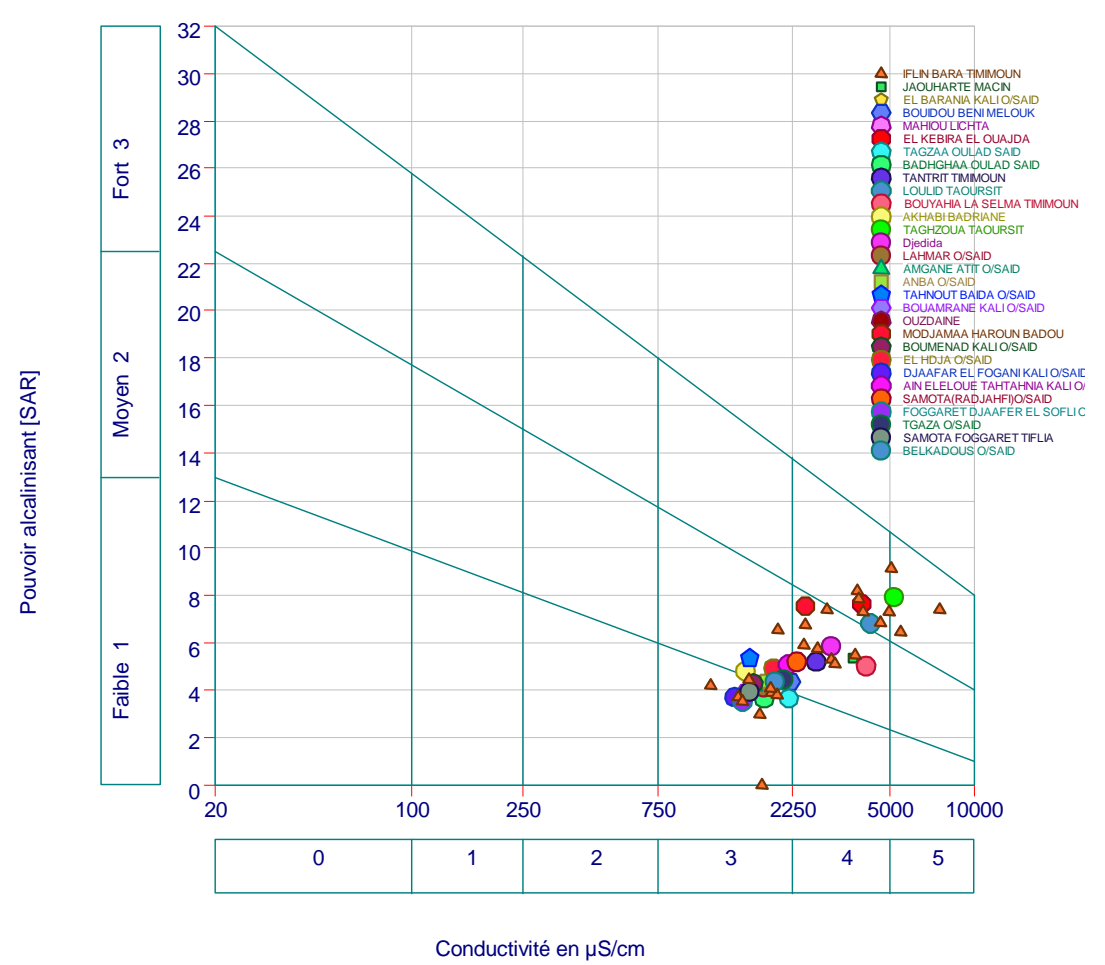

Fig.7. Salinity classes of water foggaras of Timimoune in diagram Richards (USSLS 1954)

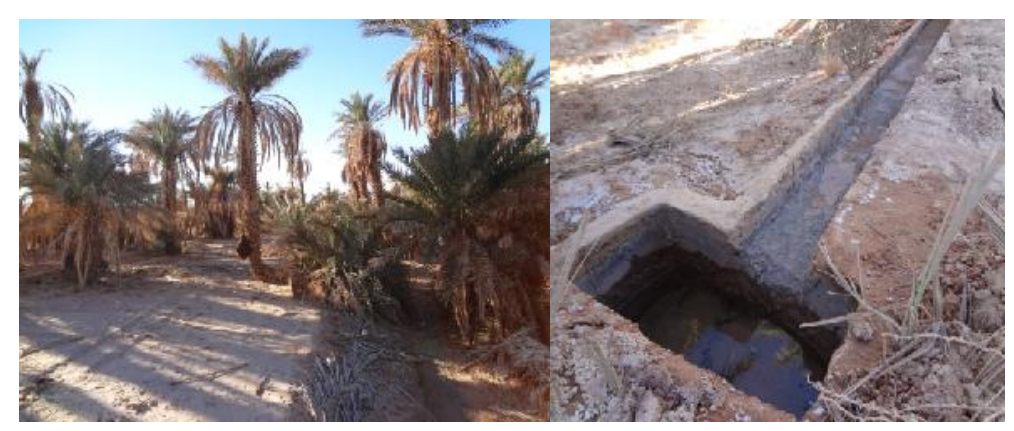

a.

b.

Fig. 8. Photos showing location of salinity in the oasis of Timimoune (Benaricha B. 2013)

(a) Deposits of salts in the plots in the oasis (b) Deposits salts in irrigation canal

\subsection{Ability of water for irrigation and effects on soil}

The quality of water used for irrigation is an important parameter to consider, not only in the study of the direct impact on agricultural products, but also in that of the indirect impact on them by modifying their physical and chemical properties of soils [22]. High salinity affects plant growth by the osmotic effect, while alkalinity to affect the permeability of the soil. 
In order to study the water quality of the aquifer for irrigation, we made recourse of the method of Richards [19]. It highlights different classes of water by the intersection between the electric conductivity and the sodium absorbable (Sodium Absorption Ratio, SAR) defined by the following equation:

$$
\mathbf{S A R}=\left[\mathrm{Na}^{+}\right] /\left[\sqrt{ }\left(\mathrm{Ca}^{2+}+\mathrm{Mg}^{2+}\right) / 2\right]
$$

After postponing all water points foggaras of Timimoune on Richards diagram (fig.7) we were able to identify the presence of the five classes [C3S1-2, C4S2-3, C5S3] corresponding to high salinity classes and very high also to the risk of medium to high alkalinity for most of the water. By the standards of the evaluation of the quality of irrigation water established by [23] in Algeria, $55 \%$ of waters of high salinity $(0.75<\mathrm{EC}<2.25 \mathrm{dS} / \mathrm{m}$ or $0.5-1.5 \mathrm{~g} / 1 \mathrm{salt}), 37 \%$ have very high salinity $(2.25<\mathrm{EC}<5 \mathrm{dS} / \mathrm{m}$ or $1.5-3 \mathrm{~g} / 1$ of salt $)$, and $8 \%$ have excessive salinity ( $5<\mathrm{EC}<20 \mathrm{dS} / \mathrm{m}$ or $3-7 \mathrm{~g} / 1$ of salt). The sodisation power (or alkalization), that is to say the SAR of waters are greater than 12 to $92 \%$ of water. Acceptable SAR values around 10 have little effect on the properties of the soil as the overall salinity is sufficient $(>0.7 \mathrm{dS} / \mathrm{m})$, but can cause toxicity by sodium [24]. The standard limit of salinity threshold is $3 \mathrm{dS} / \mathrm{m}$ at $25^{\circ} \mathrm{C}[24]$, but given the high evaporation, even the salt concentration of the water sometimes causes severe problems for plants (fig.8 a \& b). Foggaras waters are generally chlorinated sodium and potassium. The chlorine concentration is important $\geq 10 \mathrm{me} / 1$ to $78 \%$ water, which is excessive [24], and is a reason for low yields of vegetable crops in the oasis of Timimoune. The magnesium concentration in the irrigation water is considered as one of the main criteria of the evaluation of the quality of water for irrigation because the toxicity of $\mathrm{Mg}^{2+}$ ions is higher than that of $\mathrm{Na}^{+}$ions at the same concentration [25]. The $\mathrm{Mg}^{2+}$ ion is not undervalued because it represents a characteristic of saline soils of the Sahara Maghreb countries [26].

Saharan zones are the area of a secondary salinization if irrigation water is salty: there are entry saline solutions but only pure water exits by evapotranspiration. It is therefore fundamentally climatic parameters that control the relationship between the solid phases of soil and water. The essential condition for the existence of evaporative environment, salinization generator, is that evapotranspiration is much higher than the inflows. The salts 
encountered in the oasis of Timimoune mainly results from irrigation water. For example, each application of $100 \mathrm{~mm}$ of water $\left(1000 \mathrm{~m}^{3}\right)$ containing $2 \mathrm{~g} / 1$ of salt brings 2 tons of salts / hectare. One hectare plantation of date palm leaves annually between 40 and 60 tons of salts of the soluble salt content of irrigation water [27]. Thus the concentration of soluble salts increases progressively in the root zone in each irrigation to soil sterilization, unless these salts are removed by leaching and drainage. Soil sodification is the most important consequence of irrigation in arid zone. It influences the permeability by favoring swelling the dispersion of colloids. The effect of $\mathrm{Na}^{+}$of irrigation water assessed through the SAR depends on the salt concentration and water anionic facies.

\subsection{Principal Components Analysis (PCA)}

The principal component analysis (PCA) aims to project variables and individuals, from a multidimensional cloud, on planes (two-dimensional). The study was done on 13 variables and 54 individuals. The correlation matrix (Table 2) shows the strong relationship between sulfate $\left(\mathrm{SO}_{4}^{--}\right)$, chlorides $\left(\mathrm{Cl}^{-}\right)$, sodium $\left(\mathrm{Na}^{+}\right)$, calcium $\left(\mathrm{Ca}^{2+}\right)$ and the mineralization, indicating the origin evaporite saliferous and gypsiferous these waters. The projection of variables and individuals on the F1 x F2 plane is shown in Fig.9 a.

Table 2. Correlation matrix between the parameters analyzed

\begin{tabular}{|c|c|c|c|c|c|c|c|c|c|c|c|c|c|}
\hline Variables & PH & EC & $\mathbf{R S}$ & $\mathrm{NO}_{3}{ }^{-}$ & M. Ox. & $\mathrm{Ca}^{2+}$ & $\mathbf{M g}^{2+}$ & $\mathrm{Na}^{+}$ & $\mathbf{K}^{+}$ & $\mathrm{Cl}^{-}$ & $\mathrm{SO}_{4}^{--}$ & $\mathrm{HCO}_{3}{ }^{-}$ & Min. \\
\hline PH & 1 & & & & & & & & & & & & \\
\hline EC & 0.176 & 1 & & & & & & & & & & & \\
\hline RS & 0.192 & 0.970 & 1 & & & & & & & & & & \\
\hline $\mathrm{NO}_{3}{ }^{-}$ & -0.024 & 0.112 & 0.077 & 1 & & & & & & & & & \\
\hline M. Ox. & 0.012 & 0.518 & 0.537 & -0.006 & 1 & & & & & & & & \\
\hline $\mathrm{Ca}^{2+}$ & 0.190 & 0.903 & 0.877 & 0.084 & 0.516 & 1 & & & & & & & \\
\hline $\mathrm{Mg}^{2+}$ & -0.055 & 0.884 & 0.842 & 0.089 & 0.435 & 0.712 & 1 & & & & & & \\
\hline $\mathrm{Na}^{+}$ & 0.189 & 0.947 & 0.957 & 0.155 & 0.552 & 0.838 & 0.784 & 1 & & & & & \\
\hline $\mathbf{K}^{+}$ & -0.101 & 0.626 & 0.594 & 0.086 & 0.180 & 0.533 & 0.585 & 0.542 & 1 & & & & \\
\hline $\mathrm{Cl}^{-}$ & 0.139 & 0.953 & 0.950 & 0.128 & 0.544 & 0.823 & 0.846 & 0.949 & 0.564 & 1 & & & \\
\hline $\mathrm{SO}_{4}^{--}$ & 0.162 & 0.962 & 0.940 & 0.034 & 0.486 & 0.897 & 0.876 & 0.900 & 0.621 & 0.861 & 1 & & \\
\hline $\mathrm{HCO}_{3}^{-}$ & -0.054 & 0.534 & 0.492 & 0.141 & 0.266 & 0.455 & 0.408 & 0.509 & 0.631 & 0.461 & 0.481 & 1 & \\
\hline Min. & 0.176 & 1.000 & 0.970 & 0.112 & 0.518 & 0.903 & 0.884 & 0.947 & 0.625 & 0.953 & 0.962 & 0.534 & 1 \\
\hline
\end{tabular}

Bold values indicates significant correlation coefficients for a level $\alpha=0.05$ (tailed test) 


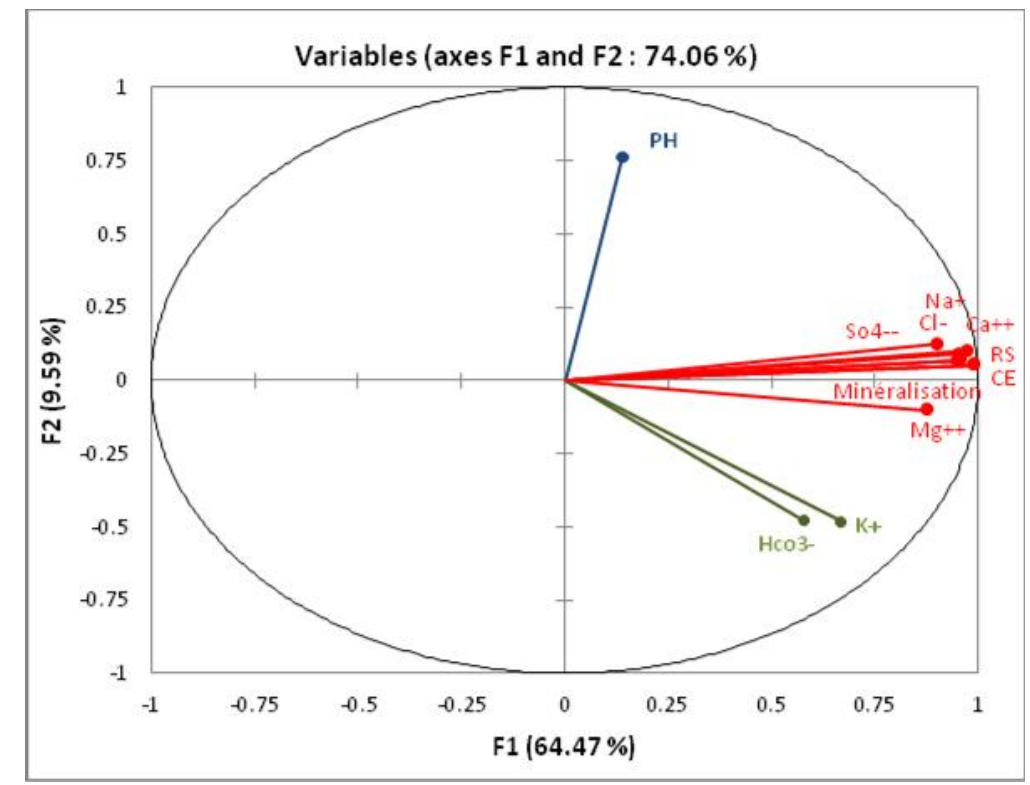

Fig. 9a. Variables projection on the F1 x F2 plane

\section{Variables study}

Table 3.Correlation between variables and axes

\begin{tabular}{|l|c|c|c|}
\cline { 2 - 4 } \multicolumn{1}{l|}{} & F1 & F2 & F3 \\
\hline $\mathrm{PH}$ & 0.140 & $\mathbf{0 . 7 6 3}$ & 0.407 \\
\hline $\mathrm{RS}$ & $\mathbf{0 . 9 9 2}$ & 0.051 & 0.018 \\
\hline $\mathrm{NO}_{3}{ }^{-}$ & $\mathbf{0 . 9 7 5}$ & 0.102 & -0.005 \\
\hline $\mathrm{M} . \mathrm{Ox}^{2+}$ & 0.120 & -0.339 & $\mathbf{0 . 8 6 9}$ \\
\hline $\mathrm{Ca}^{2+}$ & 0.567 & 0.172 & -0.228 \\
\hline $\mathrm{Mg}^{2+}$ & $\mathbf{0 . 9 0 3}$ & 0.122 & 0.011 \\
\hline $\mathrm{Na}^{+}$ & 0.879 & -0.101 & -0.107 \\
\hline $\mathrm{K}^{+}$ & $\mathbf{0 . 9 5 4}$ & 0.090 & 0.072 \\
\hline $\mathrm{Cl}^{-}$ & 0.668 & -0.482 & -0.059 \\
\hline $\mathrm{SO}_{4}^{-}$ & $\mathbf{0 . 9 5 2}$ & 0.066 & 0.020 \\
\hline $\mathrm{HCO}_{3}^{-}$ & $\mathbf{0 . 9 5 9}$ & 0.070 & -0.058 \\
\hline $\mathrm{Min}^{-}$ & 0.579 & -0.480 & 0.047 \\
\hline
\end{tabular}

Axis 1 or factor 1 (Fig.9 a) represents $64.47 \%$ of the total information. Table 3 shows that the most correlated variables with this axis: are $\mathrm{EC}, \mathrm{RS}, \mathrm{Ca}^{2+}, \mathrm{Na}^{+}, \mathrm{Cl}^{-}, \mathrm{SO}_{4}^{--}$and mineralization $(>0.90)$. It is they who are responsible for signing the mineral content of the water. Individuals who have high coordinates on the axis 1 have strong values for our above-mentioned variables (and vice versa). 
The axis 2 is $9.59 \%$ (Fig.10a.) of the total information. The $\mathrm{pH}$ is the only variable that is well correlated with this axis (Table 3), and therefore individuals who have high coordinates on the axis 2 will have high values for $\mathrm{pH}$ (and vice versa).

Table 4. Quality variable representation on axes F1, F2 and F3 $\left(\cos ^{2}\right)$

\begin{tabular}{|l|c|c|c|}
\cline { 2 - 4 } \multicolumn{1}{c|}{} & F1 & F2 & F3 \\
\hline $\mathrm{PH}$ & 0.020 & 0.582 & 0.166 \\
\hline $\mathrm{EC}$ & $\mathbf{0 . 9 8 4}$ & 0.003 & 0.000 \\
\hline $\mathrm{RS}$ & $\mathbf{0 . 9 5 1}$ & 0.010 & 0.000 \\
\hline $\mathrm{NO}_{3}^{-}$ & 0.014 & 0.115 & $\mathbf{0 . 7 5 5}$ \\
\hline $\mathrm{M.Ox}$ & 0.322 & 0.030 & 0.052 \\
\hline $\mathrm{Ca}^{2+}$ & 0.816 & 0.015 & 0.000 \\
\hline $\mathrm{Mg}^{2+}$ & 0.773 & 0.010 & 0.011 \\
\hline $\mathrm{Na}^{+}$ & $\mathbf{0 . 9 1 0}$ & 0.008 & 0.005 \\
\hline $\mathrm{K}^{+}$ & 0.446 & 0.233 & 0.003 \\
\hline $\mathrm{Cl}^{-}$ & $\mathbf{0 . 9 0 5}$ & 0.004 & 0.000 \\
\hline $\mathrm{SO}_{4}^{--}$ & $\mathbf{0 . 9 2 0}$ & 0.005 & 0.003 \\
\hline $\mathrm{HCO}_{3}^{-}$ & 0.336 & 0.231 & 0.002 \\
\hline $\mathrm{Min} .^{-}$ & $\mathbf{0 . 9 8 4}$ & 0.003 & 0.000 \\
\hline
\end{tabular}

The variables EC, $\mathrm{RS}, \mathrm{Na}^{+}, \mathrm{Cl}^{-}, \mathrm{SO}_{4}{ }^{--}$and mineralization (Table 4) are best correlated (>0.90) with the F1 x F2 plane and therefore it is they that can be interpreted. However, only the variable $\left(\mathrm{NO}_{3}{ }^{-}\right)$correlated well with the $\mathrm{F} 3$ factor and therefore it is alone contributes to the formation of this axis.

The first two axes represent a better part of the information while the other axes represent only a small part and can be neglected. But because of the good correlation with nitrates F3 factor, it was retained for future interpretation. Table 5 shows the proportion of the information represented by each axis.

Table 5. Distribution of inertia between the 3 axes F1, F2 and F3

\begin{tabular}{|l|c|c|c|}
\cline { 2 - 4 } \multicolumn{1}{c|}{} & Own value & $\begin{array}{c}\text { \% of total } \\
\text { variance }\end{array}$ & $\begin{array}{c}\text { Cumul } \\
\text { \% }\end{array}$ \\
\hline F1 & 8.381 & $\mathbf{6 4 . 4 6 7}$ & $\mathbf{6 4 . 4 6 7}$ \\
\hline F2 & 1.247 & $\mathbf{9 . 5 9 3}$ & $\mathbf{7 4 . 0 6 0}$ \\
\hline F3 & 1.000 & $\mathbf{7 . 6 9 2}$ & $\mathbf{8 1 . 7 5 2}$ \\
\hline
\end{tabular}


The Figure 9 a. represents the projections of variables and individuals on the plane F1 x F2 respectively. This plan represents $74.06 \%$ of the total information. Table quantile $95 \%$ the percentage of inertia of the first two dimensions and a number of variable equal to 13 and a number of individuals equal to 54 gives approximately $30.5 \%$. So our projection quality $(74.06 \%)$ is considerably good since it far exceeds the minimum (30.5\%). We could still see the plane F1 x F3, since the factor 3 represents $7.69 \%$ of the information (which is not negligible), and combination of the three axes of information is $81.75 \%$ (Table 5). The figure $10 \mathrm{~b}$ shows the projection of the variables on the generated map.

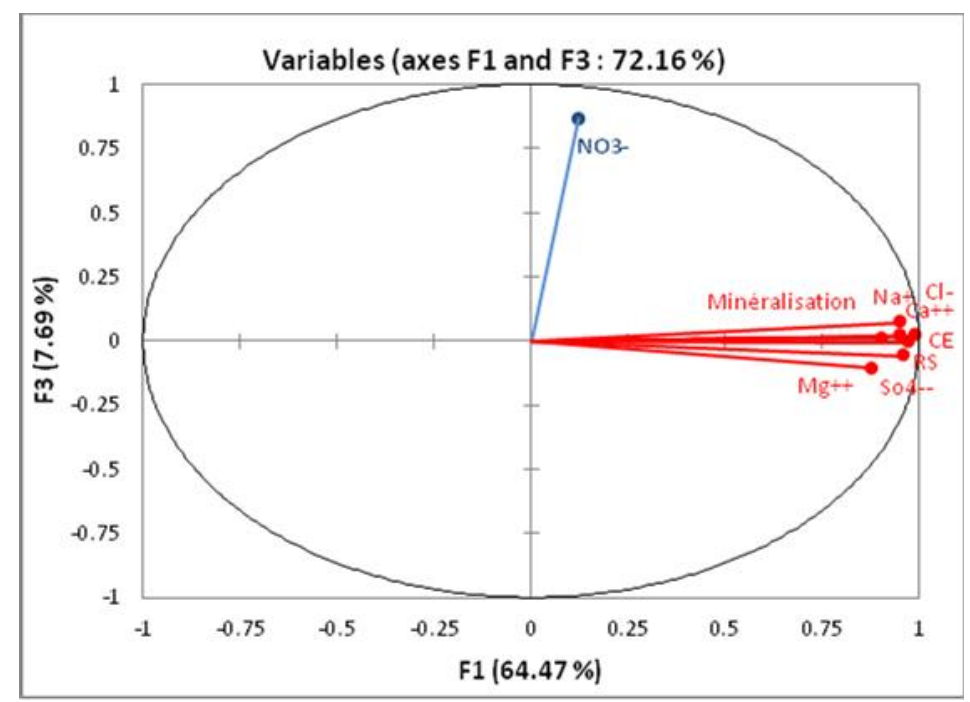

Fig.9b. Variables projection on the F1x F3 plane

The Figure 9 a shows the good correlation of the chemical elements $\left(\mathrm{Ca}^{2+}, \mathrm{Mg}^{2+}, \mathrm{Na}^{+}\right.$and $\mathrm{Cl}^{-}$ $\mathrm{SO}_{4}^{--}$) with axis 1 (which has already been noticed on the F1 x F2 plane), highlighting the mineralization of these waters and reflecting the geological natural. On the other hand, Figure 9 b. reports a very important information that is detachment of nitrates compared to other (nitrates contribute alone for forming plane F3) giving the possibility to their anthropogenic origins related to infiltration of wastewater septic tanks in the absence of sewerage system of wastewater in the region strengthening this hypothesis [28] [29], because agriculture is very traditional in oasis of Timimoune don't use fertilizer. 


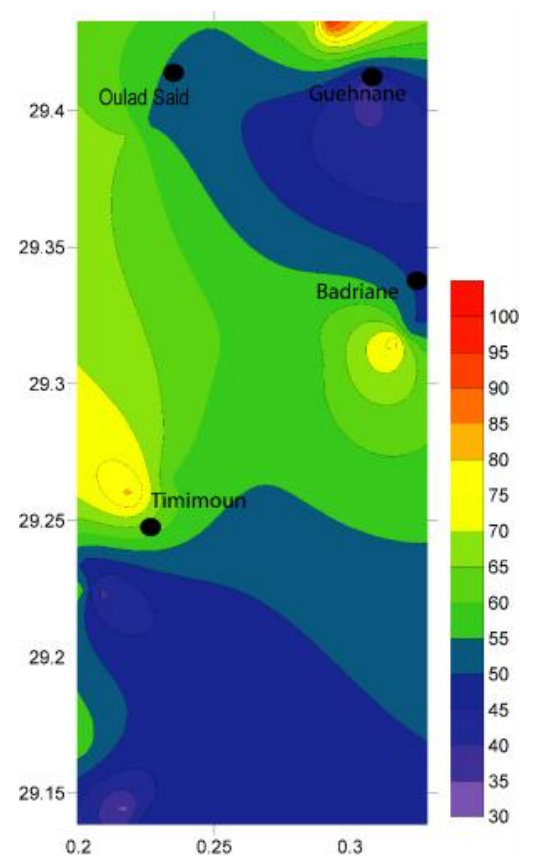

Fig.10. Iso-values map of nitrates $\left(\mathrm{NO}_{3}{ }^{-}\right)$in $\mathrm{mg} / 1$ water the foggaras

Natural sources of nitrate ion $\left(\mathrm{NO}_{3}{ }^{-}\right)$are mainly rain and soil-vegetation interactions. The nitrates are anthropogenic contamination by fertilizers, pesticides and household waste. Nitrates are not toxic to humans. However, their conversion to nitrite $\left(\mathrm{NO}_{2}{ }^{-}\right)$in the digestive tract under the action of bacteria can cause the transformation of hemoglobin "methemoglobin" blue baby syndrome from $50 \mathrm{mg} / 1$ [30]. In adults, long-term consumption is involved in the formation of nitrosamines, carcinogenic molecules. In mid natural concentration rarely exceeds $0.45 \mathrm{mg} / 1$, the water potability standard is $50 \mathrm{mg} / 1$, above 100 $\mathrm{mg} / 1$, the water is unfit for consumption. The contents of recorded nitrates greater than 50 $\mathrm{mg} / 170 \%$ of total water foggaras, $22 \%$ are between 40 and $50 \mathrm{mg} / 1,8 \%$ contents of between 20 and $40 \mathrm{mg} / \mathrm{l}$. The iso-values of nitrates card (fig.10) shows an upward gradient contents goshawks cities demonstrating the existence of infiltration wastewater from septic tanks from populated areas, and thus the anthropogenic nitrate.

\section{CONCLUSION}

The interpretation of the analytical data by different methods, showed that foggaras water of the continental slip groundwater or Albian groundwater of Timimoune region are characterized by significant mineralization averaging $2 \mathrm{~g} / \mathrm{l}$, with a dominance of chlorinated 
facies sodium. Salinity is high to very high and the risk of alkalizing medium to very high. For the highlighting of the relationship between geology and water chemistry of the studied aquifer, we have directed our research towards geochemical aspect. In fact, dissolution of these minerals seems to contribute to the acquisition of the mineralization of the groundwater. The anthropogenic of nitrate ions is confirmed by the statistical study and map highlighting a high concentration around urban centers. In a general way, the water is poor to qualify for irrigation and unfit for human consumption.

\section{REFERENCES}

[1] Kilian C. (1931), Des principaux complexes continentaux du Sahara. Comptes Rendus Sommaires des séances de la Société Géologique de France, vol. 9 pp.109-111

[2] Deleau P. (1951), Les bassins Houillers du Sud oranais dans la région de Béchar-Abadla. Bulletin du Service Géologique de l'Algérie, Livre I, Stratigraphie, 275 p.

[3] Deleau P. (1952), La région de Colomb-Béchar. Monographie Régionale, Alger, XIXe Congrès de Géologie International, 1 (8): 1-101pp.

[4] Busson G. (1967), Le Mésozoïque saharien. L'extrême sud tunisien ; CNRS.

[5] S.A.S.S. (Système Aquifère du Sahara Septentrional)., (2002) Volume 2: Synthèse hydrogéologique, p155.

[6] Gibert E. (1989), Géochimie et paléohydrologie des bassins lacustres du nord-ouest saharien. Programme Palhydaf, site 2. Thèse de Docteur en Sciences, Université de Paris Sud, Centre d'Orsay.

[7] S.A.S.S. (Système Aquifère du Sahara Septentrional Algérie, Tunisie, Lybie). (2008), Gestion commune d'un bassin transfrontalier OSS. Collection synthèse $n^{\circ} 1$. Tunis, $\mathrm{p} 48$.

[8] Gonfiantini G.., Conrad G.., Fontes J-C., Sauzay G.., Payne, B.R. (1974), Etude du Continental Intercalaire et ses relations avec autres nappes du Sahara Sept ; in : Isot techn groundwater hydrology; AIEA.

[9] Remini B. and Achour B. (2008), Les foggaras du grand Erg Occidental Algérien. Larhyss Journal, $n^{\circ} 07$, pp. 21-37. 
[10] Thioulouse J., Chessel D., Doledec S., Olivier J.M. (1997), ADE-4 : a multivariate analysis and graphical display software. Statistics and Computing Journal 7 : 75-83.

[11] Rodier J. (2005), L'analyse de l'eau : Eaux naturelles, eaux résiduaires, eau de mer. $8^{\mathrm{e}}$ édition. Paris : Dunod.

[12] Rosset R. Ben Amor M. \& Ghorbel A., (1997), Caractérisation du pouvoir incrustant des eaux d'irrigation du Cap Bon par chronoéléctrogravimétrie, Comptes Rendus Académie des sciences Paris, 325, pp.727-732.

[13] World Health Organization (WHO). (1993), Guidelines for drinking water quality, (2 $2^{\text {nd }}$ edition), Volume 1, Geneva, WHO. 130p.

[14] Rodier, J. (1984), L'analyse de l'eau : Eaux naturelles, eaux résiduaires, eaux de mer. Edition Dunod Paris.

[15] Dussart, B. (1966), Limnologie : Etude des eaux continentales. Gauthier- Villars, Ed., Paris.

[16] Bermond R. Vuichaard R. (1973), Les paramètres de la qualité des eaux. Documentation Française, Paris, 179p.

[17] Chapman D. and Kimstach V. (1996), Selection of water quality variables. Water quality assessments : a guide to the use of biota, sediments and water in environment monitoring, Chapman edition, 2nd ed. E \& FN Spon, London, pp. 59-126.

[18] Person. J. (1978), Irrigation et drainage en Tunisie problème posé par la salinité des sols et des eaux. Bulletin du BRGM, $2^{\text {ème }}$ série, section III, $\mathrm{n}^{\circ} 2$, pp.143-151.

[19] Richards L. A. sous la direction U.S.S.L.S. (United State Salinity Laboratory Staff) ; (1954), Diagnosis and improvement of saline and alkali soils.US Department of Agriculture, Handbook nº0, U. S. Gov. Print. Office, Washington DC (USA), 160p.

[20] Bakalowicz M. (2013), Les eaux souterraines : hydrologie dynamique et chimique, recherche, exploitation et évaluation des ressources. Quoi de neuf ? Dix neuvièmes journées techniques du Comité Français d'Hydrogéologie de l'Association Internationale des Hydrogéologues Bordeaux 30 mai - 2 juin 2013.

[21] Hamzaoui A.F., Bouhlila R., Gueddari, M. (2012), Caractérisation de la minéralisation des eaux de la nappe des grès du Trias (Sud-Est Tunisien) par les méthodes 
géochimiques et statistiques.Journal Geo-Eco-Trop., n³6, pp49-62.

[22] Suarez D., Wood J., Lesch S., (2006), Effect of SAR on water infiltration under a sequential rain-irrigation management system. Agric water Manage; 86: pp150-64.

[23] Durand JH., (1958), Les sols irrigables. Alger : SES, 190p.

[24] Ayers R. S., Westcot D. W. (1976) La qualité de l'eau en agriculture. Bulletin FAO d'irrigation et de drainage 29, 82 p.

[25] Szablolcs I. and Darab K. (1979), Water quality for irrigation and salinisation problems. Proceedings 3. Symposium of CIEC. Bengahzi - Lybia, 51-69.

[26] Cheverry C. and Robert M., (1993), Salures des sols maghrébins. Influence sur les propriétés physiques et physico-chimiques des sols. Répercutions de des dernières sur la fertilité, notamment azotés, des sols. Rennes : ENSA, 1993 ; 59p.

[27] Daoud Y. and Halitim A., (1995), Irrigation et salinisation au Sahara algérien Sécheresse $\mathrm{n}^{\circ} 3$, vol 5 pp151-160.

[28] Djouadi A. and Oubelaid A. (2015), Etude hydrochimique des eaux de la région de Gourara (Timimoune, Algérie). Univ, de Khemis Miliana, mémoire de master, 70p.

[29] Settou D. (2013), Etude hydrogéologique et hydrochimique de la nappe du continentale intercalaire de la région de Touat (Adrar, Algérie). Univ. de Ourgla, mémoire de master, $65 \mathrm{p}$.

[30] O.M.S. (2011), Guidelines for drinking-water quality - 4th ed. 564p.

\section{How to cite this article:}

Benaricha B., Khaldi A., Elouissi A., Mouassa S., Zaagane M.geochemical characterization the waters of foggaras the continental intercalary aquifer of timinoune region (south west algeria). J. Fundam. Appl. Sci., 2017, 9(1), 51-73. 